\title{
GLOCALIZATION AND LOCAL ALTERNATIVE ECONOMIC SYSTEMS: THE CASE OF THE SLOVAK REPUBLIC
}

Iveta UBREŽIOVÁ, Department of Management, Faculty of Economics and Management, Slovak University of Agriculture in Nitra, Tr. A. Hlinku 2, 94976 Nitra, Slovakia, iveta.ubreziova@ uniag.sk (corresponding author)

Elena HORSKÁ, Department of Marketing, Faculty of Economics and Management, Slovak University of Agriculture in Nitra, Tr. A. Hlinku 2, 94976 Nitra, Slovakia, elena.horska@gmail.com.

Kamila MORAVČíKOVÁ, Department of Management, Faculty of Economics and Management, Slovak University of Agriculture in Nitra, Tr. A. Hlinku 2, 94976 Nitra, Slovakia, kami.moravcikova@ gmail.com.

Andrea UBREŽIOVÁ, project UBM, de Entreé 73, Toren A, 1101 BH, Amsterdam Netherlands, adi.ubrezi@ gmail.com.

The main objective of the paper is to introduce the term glocalization from economic as well as from sociological point of view and to describe the concepts of alternative economies. Companies and firms are no longer operating only in their domestic markets, but they are considered as international corporations with customers in all parts of the world. Marketing departments of these companies try to understand conditions and cultural traditions in different regions of the world, otherwise there is no chance for the company to be successful in international and even global level. Localization, as very important part of glocalization, offers us opportunity to think about alternative economic systems and to confront it with globalization. Therefore, alternative economic systems and its two basic types are described theoretically and then, we introduce their practical implementation in social reality. We point out the attention on the examples from the Slovak Republic and highlight the background of origins and problems connected with establishing of these systems. Finally, we summarize the most important facts which result from the comparison of the systems. ${ }^{1}$

Keywords: alternative economy globalization, glocalization, LETS (Local Exchange Trading Systems), localization, time banks

\section{INTRODUCTION}

This paper is focused on topic which does not have long history and is not too emphasized - glocalization. Currently, in today's globalized world, this issue is still more and more important and many businesses act according to the main idea of glocalization: think globally, act locally or vice a versa.

Basically, the term glocalization is combination of two words: globalization and localization. The relationship between them is quite important, although many scientists define global and local as opposites. Localization, as very important part of glocalization, offers us opportunity to think about alternative economic systems and to confront it with globalization. Along with global - glocal tendencies, there exist mechanisms that run on the same principles but their basic objective is to activate local human and also material resources. They do not follow principles of market economy but they try to alter it while their basis is non- profit making. The terms LETS and Time Banks are not so known neither among economists nor among public. Nevertheless, this topic becomes more and more important within the strategies of rural development in the European Union in contemporary period. Local communities offer interesting way how to cope with today's difficult age.

The part of the paper dealing with alternative economic systems describes two basic types of those systems and their practical implementation in social reality. We are going to point out the attention on the examples from the Slovak Republic and to highlight the background of origins and problems connected with establishing of these systems. Paper is covering the literature that deals with the topic of glocalization and with alternative economic systems. It is quite difficult to find relevant sources of information and also more current ones about certain issues we are dealing with. When writing the paper, we used mainly method of literature research and analysis of findings about Local Exchange Trading Systems (LETS) and Time Banks (TB). The resources consist of various books, online publications and

\footnotetext{
1 The publication of scientific article is supported by the Slovak Scientific Agency VEGA - Project VEGA No. 1/0044/13 " Corporate Social Responsibility (CSR) of the Slovak Enterprises in the context of Internationalization in Business"
} 
documents found on the Internet. As mentioned, there is limited amount of resources dealing with LETS and Time Banks in the Slovakia. On the other hand, those sources offer sufficient information and are very useful for our observation on this topic.

\section{RESULTS AND DISCUSSION}

\section{Importance of Relationship between Globalization and Glocalization}

When considering who is behind the origin of the idea of globalization, we have to understand that both sociology and economy find it very challenging, as various ideas and theories are not creations of one mind but are results of collective thinking. Therefore, it is not possible to state, who had used the term globalization for the first time. (Khondker 2004; Pollifroni 2006) This term does not have a long history, although in English language it was firstly used in 1960's. (Beyer 2011) It has gained bigger importance and became more common term in 1990's, although McLuhan's theory of seeing the world as "global village" (McLuhan 1964) was known already in the early 1960's. In the case of sociology, its history is much shorter. In 1990's, this term was not mentioned in any dictionary of sociology as a single term, it could be found only in connection with globalization theory or connected with globalization on production. We have to distinct between globalization as a term and globalization as a social process that is much older. (Moravčíková 2010) Other authors, as Ubrežiová I. with Ubrežiová A. (2012) explain that this process was and is still visible in culture and religion, in relationships among individuals, groups and communities that cooperate by trading. According to Giddens (1990), globalization is "the intensification of worldwide social relations which link distant localities in such a way that local happenings are shaped by events occurring many miles away and vice a versa." Beck (2003), following the theory of Giddens, stated that globalization means "acting and living (together) over distances, across the apparently separate worlds of national states, religions, regions and continents". In general, sociology is a science studying modern societies and thus, when local communities extended to a global society, the global society became the basic aim of the sociology.

Logically, relationship between the terms globalization and glocalization is very close, although they are really different indeed. The important fact is that the local is usually formed by the global or backwards. Local traditions and customs were created on the base of interactions among various cultures. It is very understandable process as minorities and elites try to maintain their traditions abroad and that is also the reason why new mixed cultures develop. The very used term for these new mixed cultures is "hybrid cultures". To adopt to the needs of such cultures, international corporations use two marketing strategies when entering the new market - globalized and localized strategy. Globalized strategy means that the corporation applies the same marketing strategy all over the world and does not adapt to local needs and customs. In other words, we can say it is the case of standardization because corporation offers standardized products and uses standardized marketing mix all over the world that is considered as single market. (Kotler 2009) On the other hand, localized strategy means that corporation tries to understand local needs, customs and traditions, simply said to know deeply the local culture and minds of the customers in the local market. The theory of glocalization is combination of these two strategies. (Volkmann 2009) The concept of glocalization is closely connected with the Japanese model dochakuka what means global localization and is derived from the word dochaku - living on one own's land and was firstly defined by Robertson (1995). This system was based on adaption of farming techniques to local conditions and later applied in business level where global products were fitted to local needs. In the 1990's, Roland Robertson, sociologist from the United Kingdom, firstly introduced the term glocalization and later was followed by sociologists Keith Hampton and Barry Wellman from Canada and also by Zygmunt Bauman from Poland. In social science, the term glocalization is often replaced by the term indigenization. (Khondker, 2004; Pollifroni, 2009). Nowadays, according to Wordspy (wordspy.com), glocalization means "the creation of products or services intended for the global market, but customized to suit local cultures."

\section{Glocalization vs. Alternative Economic Systems}

As mentioned in the previous part of the paper, the new mixed cultures, called hybrid cultures help us to draw connection between glocalization and alternative economic systems. According to Roland Robertson (1995), glocalization is characterized by the parallel trends of homogenization and heterogenization. Successful international corporations use global models all over the world and on the other hand, local communities assume these effects in accordance with their local traditions and customs. Although many manifestations of globalization use universal principle as alternative economies, the basic difference is that those global processes have to adapt to local needs in order to be successful. On the other side, the main objective of alternative economies is to mobilize own resources in local community and what is the most important, they are not based on profit. In economic anthropology, opposites are defined in models of so called community and market economy. In practice, economies are combinations of both models, but their equilibrium is changing and the solution is complicated as the cyclic reproduction is an act of mutual action, although the exchange invades social tights and leads to competition and rivalry. Many economic theories are aimed at first or second ending of this continuum, but on the other hand, many ethnographical studies show mixed, complementary and dialectical character of economic practices; and recommend some of methods, where the market economy is embedded to community economy. (Moravčíková 2010) Therefore, next part is oriented on the description of two basic models of alternative community economy - LETSystems and Time Banks, which are used all over the world. The description emphasizes the main principles and the differences between them. 


\section{What are LETS?}

Generally, LETS stands for LOCAL EXCHANGE TRADING SYSTEMS. Following Taris (2003), "Local Exchange Trading System (LETS) is known a locally initiated, democratically organized, not-for-profit community enterprise which provides a community information service and records transactions of members exchanging goods and services by using the currency of locally created LETS Credits." In this type of local economic system no coins, paper money and tokens are used. It is simply a community which creates its own currency to exchange goods and services without using the national currency. Names of LETS Credits differ from system to system and usually, the name of credits is made out by adding to it a "local flavor". (Pam 2004; Taris 2003) Although names of LETS are not the same, all those systems work on similar principles. (Jakubec 2001) When talking about LETS, it is very important to mention Michael Linton since he had had used this term for the first time in 1983. Originally from Great Britain, Michael Linton immigrated to Canada where he examined various relations in social and environmental sphere. Later he found out that trading in local community was closely connected to the flow of national currency to local economy. There were not enough money what led to decrease of trade, then to increase rate of unemployment and more and more social problems. Although there were enough commodities and skilled people, the lack of money caused the trade was decreasing. As a result, Linton's idea of "complementary currency" was established and the Comox Valley LETS in Courtenay, British Columbia was the first community that applied LETS. (Douthwaite 1999) This currency was supposed to help the people to build sustainable community and to eliminate social, environmental and other problems. (Jakubec 2001) What is really important to say is that LETSystem acts only as something additional to national currency, without any intention to replace it. It is not based on any commodity, rather than act as the modern equivalent to normal currency since they allow people to make means of payments by themselves. Put in simply, everyone can imagine that LETS work like a babysitting organization. People involved earn credits by babysitting other member's babies and later spend these credits whenever they need to take care about their child. Usually, LETS are set up by people who dispose of too much time but face to lack of national currency to satisfy their needs. LETS can be applied in many fields, but usually it directs to whatever is available locally. A successful LETS can assure people involved in it with whatever they need, usually with commodities such as food, clothes, housing, transfer and many others. Very specific for these systems is the fact that everything is based on local credits and does not have any connection with national currency. (Douthwaite 1999; Taris 2003)

\section{What are Time Banks - TB?}

Time Banks are new, interesting and exciting way how people can come together into some community where they help not only themselves but to the others, too. We can say, time banking is basically about spending an hour doing something for someone else in your community. These hours are counted in the Time Bank as credits and one hour is equal to one credit. Then, if you deposit your one credit you have possibility to spend it and someone else will spend one hour doing something for you. It is really powerful tool in building relationships within the community, because every participant becomes giver and also the receiver. People are getting to know the best in the others. ${ }^{2}$ Basically, the main principle of Time Banking is that people does not accumulate debts, they just accumulate time which they have used. This system is not based on monetary units. Time Banks are all about hours and there is no difference between one hour spent by taking care of baby and one hour spent by building a house. Building of social relationships on the base of time is really equitable besides all the other aspects. It does not matter if someone is rich lawyer or old poor woman. (Poláčková, 2002) There are two types of time banks: community time banks and specialist time banks. Community Time Banks or neighbor-to-neighbor time banks are based on cooperation of participants within the local community. If it is possible, community time banks try to create and support organizations with similar aims although they are not involved in the community. Their main objective is to develop social relationships of mutual aid, where every person has different abilities. The relationships among different generations in community are stronger but the most important is the fact that services differentiation is created. The first case is that of Elderplan, in the Brooklyn area of New York. Specialist Time Banks are based on the same mechanism, but operate within homogeneous groups whose members have similar skills available. This is the case with hospices, schools and other interest groups that tend to utilize the exchange within the group and for a set objective.

\section{Alternative Economic Systems and Their Application in Social Reality}

Along with global - glocal tendencies, there exist mechanisms that run on the same principles but their basic objective is to activate local human and also material resources. They do not follow principles of market economy but they try to alter it while their basis is non- profit making. The terms LETS and Time Banks are not so known neither among economists nor among public. Nevertheless, this topic becomes more and more important within the strategies of rural development in the European Union in contemporary period. Local communities offer interesting way how to cope with today's difficult age. Time money offers opportunity also to those people which were rejected by accustomed market and which are having problems because of the current economic system. They also create new moral imperative - never to waste with human abilities. Money in LETS are private and invisible. It is not possible to steal them or to sink them and community still have only as much money as it needs, it means how the members are willing to work. That is also its biggest disadvantage - they cannot be gained without work or by bluffing, stealing and blackmailing.

${ }^{2}$ http://www.timebanking.org/about/what-is-a-timebank/ 
In the Czech Republic, there had been three LETS operating since 1990s in Prague, Brno, České Budejovice. The one in the capital, Prague, was established under Agency GAIA in 1999. Its currency was called "chechtáky" ("smiling money"). In 2001, it had around 100 member from which 20-30 were active. Following Konečný et al. (2012), this LETS finished few years ago. Similar is also the end of another LETS in České Budejovice under the name "Letokruh" ("Annual ring") that was established in 2000. After four years of operating, it has more than 50 members that agreed on currency called "žalud" ("acorn") that was equal to 1 CZK (Czech Crown). ${ }^{3}$ The destiny of the last LETS in Brno is the same, even though it was only one where collective meeting were organized. Its maximum number of members was around 40. It was operating since 1999 till 2006. However, after ceasing of all activities of above mentioned LETS, there were few other attempts to begin new LETS (in Litomysl), but its activities finished as well. (Konečný et al., 2012).

When speaking about Time Banks, it is possible to mention the company Timebanking UK. They are the only one company that provides support and resources to community TB and help them with inspiration, help and practical information. Currently, they gather approximately 300 time banks from all over the UK with different fields of interest. In other terms, it means there are more than 31,000 people involved and around 3,700 organizations. ${ }^{4}$ Similar organization exist in the USA under the name Timebanks USA. Located in Washington D.C., it was established in 1995 with goal to affect individuals, families, youth, communities, nature and whole world. ${ }^{5}$

\section{Zaježka}

In Slovakia, approximately $15 \mathrm{~km}$ southwest of Zvolen, in the middle of mountains called Javorie, little village Zaježová lies. For centuries, fertile soil was the basic source of subsistence for the inhabitants of this small mountain valley. In the second half of the $20^{\text {th }}$ century, young people started to leave the area with a vision of a better life in bigger towns. At the beginning of the nineties mostly the elderly remained. Statistically said, from 600 inhabitants, the number decreased to 190 in the year 2000. Zaježová was "discovered" after the year 1989 by people interested in traditional culture who established The School of Folk Culture here. Its objective was mainly to reintroduce the traditional crafts of our predecessors to the youth. "Zaježka" became popular very quickly and hundreds of people visited its many workshops and summer camps. As a result, the young people who like these activities came there for the first time. In that time, they decided to found an organization called Society for Harmonious Living. Main inspiration for those people is the simple, modest and self-sufficient lifestyle, such as their predecessors had in the past. But it is important to say that they are not trying to enforce a return to the way of life of 100 or more years ago. It is just ecological and societal alternative to the system of today's world in practical life. People, who immigrated to Zaježová and lived there in the mountain settlement, have come there to share values with other people and to live life in real nature. They called themselves "newcomers". Those people have agreed on regular meetings at which they try to discuss everything they have gradually done to create a functioning community. This community should be maximally self-sufficient and should ensure all of the functions which belong to community. The first themes inhabitants were discussing dealt with conception of local economy and external economy (work for the national currency). Newcomers have realized that without functioning system, the other people will not come into uncertainty. In the next meeting they discussed issues about the local economy and about various models of non - monetary mutual exchange. After that (at the end of April 1999) the LETSystem was agreed. On the next meeting the name of unit was agreed. As it is in Zaježová, the unit was called "jež"("hedgehog"). It was derived from hours of work (hour is not subject of inflation), so 1 hour $=10$ jež. Social character of this system does not look at the differences in intensity, fastness and physical ability of individuals. They also agreed operating rules, book of accounts (ledger "Ježovník"), method of accounting, etc. At the next meeting in May they signed a social agreement on LETS. But business has practically run from April under certain agreements. Problems were only in establishing the unit. What should be the base of the unit - money or something natural, which is not subject of inflation (e.g. kilogram of carrots is after 20 years still kilogram of carrots). It is difficult for people used to monetary system to valuate things in different base and to use the other concept of counting. Sometimes the trade turnover per week was low, but the situation was gradually improving. The biggest trade recorded was 400 Ježov and it was for manufacturing of windows on Pastiareň. ${ }^{6}$

\section{Time Bank in Rajecké Teplice}

In general, the Time Bank system is highly developed in the United States and Great Britain. But also Japan does not have to be ashamed of its successes in this system, where it is used to solve the problem of pensioners. Opposite situation is in Rajecké Teplice. Children create the biggest group of members in the Time Bank, which was officially opened on 2 February 2001 in Rajecké Teplice. It is operating under the protective wings of the Civil Association - Culture. Few years ago, Culture Civil Association - Culture was only the idea of a few enthusiasts who thought that they will change the world if they establish a Civil Association. The association had two basic lines of activities from which the first one are children and youth program, and the second is program to support volunteering in the region. In the first line existed and operated 16 children's groups, 4 children's clubs, a youth club, children's festival "RaRadosti"("HaHapiness"), international school of arts and crafts, and many other activities. In the second line of action, the organization seek to encourage the widest possible range of citizens in volunteer activities, organize training programs, implementing the European Voluntary Service program, preparing conditions for the realization of the people

\footnotetext{
${ }^{3}$ http://gaia.ecn.cz/projekty/lets.html, http://www.lets.ecn.cz/letsvcr.php

${ }^{4}$ http://www.timebanking.org/about-tbuk/

5 http://timebanks.org/about/

${ }^{6}$ http://www.zajezka.sk/
} 
around. Both lines of action are related to the Time Bank system. At a time when there was the most intensive debate whether the children should pay for membership, the Association discovered the system of Time money. It was a small "gift from heaven" that shifted debate into an entirely different plan. It brought into discussion the issue of value of traditional money as well as the issue of cohesion in the community. The Administration Board has found that when it starts to charge for the activities by traditional money, the amount will never be so high to affect the budget and financing of the organization. The most important will be that organization finds people who are willing to work even the organization will have reduced financial means or will suspend their activities. The Board therefore decided that the children will pay for offered activities by the time money. Price for one month was 2 time credits - that means two hours of volunteering for the community. This had also another dimension - children have to pay for activities by their own and nobody is allowed to pay it instead of them.

In September 2001, the system began to be tested in practice. Organization opened the six very small, independent banks. No one knew whether the system will be functional in reality and what it will bring. Banks operate in the individual rings and none of them had more than 15 members. Trade took place within the group and was overseen by their own members - children that also managed it. The system was verified in four of the six groups and the responses were more than positive. In one group also the Bank Board, executor and banker were selected. Based on the experience, the association decided to open a real Time Bank, which began to match children and adults who do not know each other and also the children, who do not attend any of the activities created by the association. During the opening ceremony it was voted that the currency in the first Slovak Time Bank will be called "prašulák" and will be backed by one hour of work. To the date 1 February 2002 - almost one year after the opening ceremony of the bank, it has 119 active members per month with average earn 334 prašulák - it means 334 volunteer hours. The members, except of the exchanging services (which is 115 available from shopping, tutoring different subjects, assistance in home gardens and to services such as "I give good advice") and depositing of prašulák to own accounts, can buy: access to the Internet, work with computer, business shirts, visit of the cinema or a lottery ticket.

\section{CONCLUSION}

The basic objective of glocalization is not only to assure stable and integrated world but also to protect local traditions and cultural heritage of communities. The term local economy is really important issue in today's world not only because it helps people involved in these systems but it improves the quality of interpersonal relations, too. Mostly, local economies are provided by informal groups of enthusiasts, neighborhoods or they work within the environmentally and socially oriented non-governmental organizations. They help to activate human potential and solve problems caused by the current economic system. It is not difficult to find differences between various types of LETS and Time Banks. While TB value everyone's time equally (you give one hour and you have one hour to spend), LETS' members create their own currency and also set its value. The next difference is based on conceptual setup. The exchange between members in LETS is more simple and direct as they are trying to build an alternative economy. In $\mathrm{TB}$, this exchange is not direct, usually is done through coordinator and also, TB are trying to cooperate with external and public organizations. ${ }^{7}$ In general, LETSystems are usually used in rural areas and in rural communities, while Time Banks are more common in urban municipalities - in their particular communities, especially within social and health institutions, volunteer organizations and charity.

In Zaježová, many people are trying to carry out ecological and social alternative to today's system in practice. We can talk about the emerging community or community open to new people. In Zaježová arose also probably the first real LETS system in the Slovakia. The next organization we can find in Trnava was tittled "Trnavský spolok gazdovský“, running from March 2002. In the capital of Slovakia, Bratislava, there had been two organizations. The first of them - "Svojpomoc"- established in October 2001 and the second one in March 2002 where the LETS was provided by the association "Environmentálna poradňa Studnička o.z.", with the residence in Dlhé diely. There have been also few other ones, such as in Revúca ("Vzájomná pomocnica"), Vráble (family farm "Mašekov Mlyn”), Košice ("BioLets" - based on exchange of bio-food). Most of them are not working anymore, or they are providing just several activities. The problem of LETS in Slovakia could be the fact that only a few people are involved and all of them have some employment, so they have less time for local trading.

Time Bank in Rajecké Teplice is the first of its kind in the world. As the first it involved completely new target group that are children and try to encourage them to develop programs for other children. The biggest benefit of the Time Bank is its ability to engage people regardless of their "market value" to move from passive to active position, as well as to motivate them to help to their environment. The added value of the Time Bank, which may not be obvious at first glance, is to create relationships between strangers, which are very useful in building community and reducing anonymity. The next, pretty new Time Bank in Slovakia is called BartTime and was created two years ago by young, enthusiastic people.

It is very important to say that local alternative economies do not want to replace the official economy; they act as additional forms of economy. It is one of possible ways to activate local human potential and local sources. On the other hand, they support strengthening of the local social ties and networks. Altogether, the future of alternative economic systems in Slovakia is pretty difficult to predict as there are not enough information about such systems and many of them are not working anymore.

\footnotetext{
${ }^{7}$ http://www.timebanking.org/about/what-is-a-timebank/
} 


\section{REFERENCES}

1. Beck, U. 2003. What is globalization? USA: Blackwell Publishing Ltd., 2003. 183 p.

2. Beyer, P. 2011. Globalization and Glocalization. [online] London: Sage Publications, 2011. Available at http://www.sagepub.com/oswmedia3e/study/chapters/handbooks/handbook12.2.pdf (accessed on 2014/01/08).

3. Douthwaite, R. 1999. Ekológia peňazí (“Ecology of Money”). Dolný Kubín: DiveRzita, 1999. 77 p. (in Czech).

4. Giddens, A. 1990. The Consequences of Modernity. Stanford University Press: Stanford, CT, 1990.

5. Jakubec, I. 2001. Předpoklady a principy fungování LETS. (“Assumptions and principles of LETS working”). Available at http://lets.ecn.cz/clanek.php?slozka=cojelets\&soubor=ppfobsah (in Czech).

6. Khondker, H. H.. 2004. Glocalization as Globalization: Evolution of a Sociological Concept. Bangladesh e-Journal of Sociology, Vol. 1, 2, Available http://mukto-mona.net/Articles/habibul_haque/Globalization.pdf (accessed on 2011/02/22).

7. Konečný, A., Szalay, Z. E., Jelínek, P. 2012. Local Exchange Trading Systems in Central European post-Communist Countries. International Journal of Community Currency Research, Vol 16, No. 1, pp. 116-123.

8. Kotler, Philip, et al. 2009. Marketing Management - European Edition. Harlow, England: Pearson Prentice Hall Publishing, 2009. pp. 467-468.

9. Levitt, T. 1983. The Globalization of Markets. Boston: Harvard Business Review.

10. McLuhan, M. 1964. Understanding Media. New York: Mentor.

11. Moravčíková, D. 2010. Vidiecke obce v podmienkach transformácie. ("Rural communities in the condition of transformation”). Nitra: SPU Nitra, 135 p. (in Czech).

12. Nederveen, P. 2004. Globalization and Culture. Lanham, Maryland: Rowman and Littlefield.

13. Poláčková, Z., OZ Kultúra. 2000. Ekonomika.tvorivo.sk. Časová banka v Rajeckých Tepliciach | Iná ekonomika. ("Time Bank in Rajecké Teplice"). Available at http://ekonomika.tvorivo.sk/clanok/19/casova-banka-v-rajeckych-tepliciach .

14. Pollifroni, MASSIMO. 2006. Globalization and Glocalization: an Epistemological Analysis from Business Economics. Turin: Department of Business Administration, 2006. 16 p.

15. Pam, A. 2004. LETS: The economic system of giving. Available at http://www.glasswings.com.au/utopia/lets.html.

16. Robertson, R. 1995. Global modernities. London: Sage Publications, 1995. Glocalization: Time-space and homogeneityheterogeneity, pp. 25-44.

17. Taris, J. 2003. Lets-linkup.com. New Community Quarterly (Australia) May 2003 [All About LETS - LETS-Linkup. Available at http://www.lets-linkup.com/080-All\%20About\%20LETS.htm (accessed on 2010/04/25).

18. Ubrežiová, I., Ubrežiová, A. 2012. Corporate social responsibility in the context of global processes. Acta Oeconomica Universitatis Selye, Vol. 1, No. 2, pp. 207-218.

19. Volkmann, K. 2009. Solidarity economy between a focus on the local and a global view : Regional currencies in Germany, Austria and Switzerland. In University of Potsdam: Faculty of Economics and Social Sciences, 23 p. Available at http://base.socioeco.org/docs/a1-145-1-pb.pdf.

\section{Internet resources:}

1. Timebanking.org [online]. n.d. [cit. 2014-01-10]. What is time banking. Available at WWW: <http://www.timebanking.org/about/what-is-atimebank/>.

2. Zajezka.sk [online]. n.d. [cit. 2014-01-10]. Zajezka. Available at WWW: 〈http://www.zajezka.sk/ENindex.htm〉.

3. Guardian.com [online]. n.d. [cit. 2015-01-09]. Bristol pound local currencies. Available at WWW: <http://www.theguardian.com/localgovernment-network/2013/jun/17/bristol-pound-local-currencies>

4. http://www.wordspy.com/words/

5. http://gaia.ecn.cz/projekty/lets.html

6. http://www.lets.ecn.cz/letsvcr.php

7. http://timebanks.org/about/ 